January 2021

\title{
The Impact of Implementing a 25-Year Reversion/Termination Right in Canada
}

\author{
Paul J. Heald \\ University of Illinois, Champaign-Urbana
}

Follow this and additional works at: https://digitalcommons.law.uga.edu/jipl

Part of the Intellectual Property Law Commons

\section{Recommended Citation}

Paul J. Heald, The Impact of Implementing a 25-Year Reversion/Termination Right in Canada, 28 J. INTELL. PROP. L. 63 (2021).

Available at: https://digitalcommons.law.uga.edu/jipl/vol28/iss1/3

This Article is brought to you for free and open access by Digital Commons @ University of Georgia School of Law. It has been accepted for inclusion in Journal of Intellectual Property Law by an authorized editor of Digital Commons @ University of Georgia School of Law. Please share how you have benefited from this access For more information, please contact tstriepe@uga.edu. 


\section{The Impact of Implementing a 25-Year Reversion/Termination Right in Canada}

\section{Cover Page Footnote}

Albert J. Harno \& Edward W. Cleary Chair in Law, University of Illinois, Champaign-Urbana. This study represents the views of the author only and not necessarily those of the Department of Canadian Heritage or those of the Canadian Government. 


\title{
THE IMPACT OF IMPLEMENTING A 25-YEAR REVERSION/TERMINATION RIGHT IN CANADA
}

\author{
Paul J. Heald*
}

* Albert J. Harno \& Edward W. Cleary Chair in Law, University of Illinois, ChampaignUrbana. This study represents the views of the author only and not necessarily those of the Department of Canadian Heritage or those of the Canadian Government. 
Journal of Intellectual Property Law, Vol. 28, Iss. 1 [2021], Art. 3

\section{TABLE OF CONTENTS}

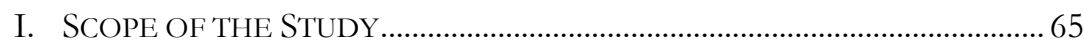

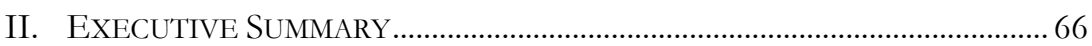

III. BACKGROUND AND METHODOLOGY............................................................ 68

IV. Private Benefits of Rights Reversion ……………………………........ 69

V. Public Benefits of Rights ReVERSoin..................................................... 71
A. Negative EfFects of Term Extension On BOOK AVAILABILITY ……………………………………………………….... 71
B. EFFECT OF TERM EXTENSION ON BOOK PRICES ............................. 74
C. RigHTS REVERSION INCREASES THE AVAILABILITY

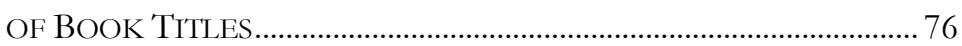

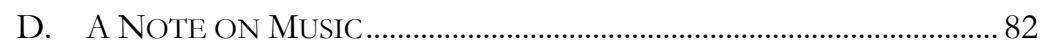

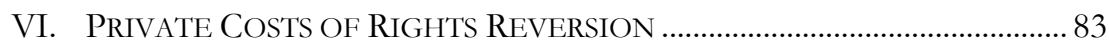

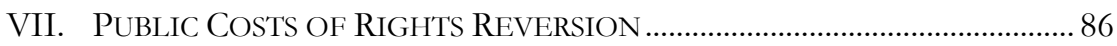

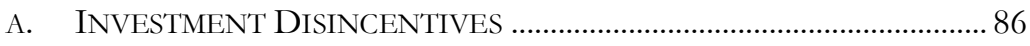

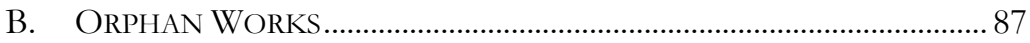

C. Derivative Works And the Problem of Hold-Up ................. 88

D. WhO CAN EXERCISE THE TERMINATION RIGHT ………………......90

E. SPECIAL Music ISSUES.......................................................................... 91

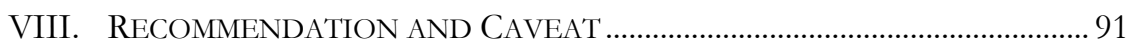


Demo2 (Do Not DeleTE) 1 1/12/2021 5:41 AM

\section{SCOPE OF THE STUDY}

After hearing extensive witness testimony, the Standing Committee on Industry, Science and Technology (INDU) and the Standing Committee on Canadian Heritage (CHPC) recommended changes to the statute governing the reversion of copyrights to authors. ${ }^{1}$ Section 14(1) of the Copyright Act currently provides that the copyright in a work reverts automatically to the author's estate 25 years after the author's death. ${ }^{2}$ The operation of the present reversion right is unrelated to the date of initial publication of the work or the date of assignment for the work; therefore, the right often vests long after publication. For example, the rights to a book published when an author was 27 , and who lived to be 82 , would revert to the author's heirs 80 years after its initial creation.

Both committees concluded that authors or their estates should be granted a non-assignable, non-waivable right to regain control over a copyright at an earlier moment, 25 years after the author's initial assignment of rights in the work:

Recommendation 8 - That the Government of Canada introduce legislation amending the Copyright Act to provide creators a non-assignable right to terminate any transfer of an exclusive right no earlier than 25 years after the execution of the transfer, and that this termination right extinguish itself five years after it becomes available, take effect only five years after the creator notifies their intent to exercise the right, and that notice be subject to registration;

INDU Report 16, "Statutory Review of the Copyright Act," *6

Recommendation 14 - That the Government of Canada amend subsection 14(1) of the Copyright Act so that it reads "from 25 years after assignment." [rather than the current 25 years from the death of the author]

CHPC Report 19, "Shifting Paradigms," *2

The present study was commissioned in December 2019 by Canadian Heritage to study the impact of introducing a non-assignable right to terminate any transfer of an exclusive right (also known as a termination right) or of amending rights reversion, as described in the recommendations of each report. This study reports an empirical and qualitative analysis of the potential

1 Canada, Parliament, Statutory Review of the Copyright Act: Report of the Standing Committee on Industry, Science, and Technology, 42nd Parliament, 1st Sess. (June 2019) (Chair: Dan Ruimy); Canada, Parliament, Shifting Paradigms: Report of the Standing Committee on Canadian Heritage, 42nd Parliament, 1st Sess. (May 2019) (Chair: Julie Dabrusin).

2 Copyright Act, R.S.C. 1985, c C-42, s. 14, par. 1. 


Demo2 (Do Not Delete) $1 / 12 / 2021 \quad 5: 41$ AM

advantages and disadvantages of the two recommendations made to Parliament in the context of the Copyright Act and the Canadian marketplace. The study focuses on literary copyright, and to a lesser extent music copyright, for two reasons. First, available data on rights reversion has been collected primarily on the market for books. Second, reversion is likely to be less important for other sorts of valuable works, like computer programs or video games, which are often works-made-for-hire (and therefore not subject to reversion) and which usually have a shorter economic life than books or music.

\section{EXECUTIVE SUMMARY}

This report tentatively recommends the adoption of a modified version of the proposal offered by INDU. Although the benefits of both proposals would likely be similar, the INDU proposal may offer lower transaction costs. The empirical data gathered in this report support the conclusion that a carefully crafted termination right would provide measurable benefits to both authors (or their estates) and to the Canadian public. As explained below, potential costs are minimal and clearly outweighed by economic benefits.

In light of the available data, the recommended termination right should:

i. $\quad$ provide creators a non-assignable, non-waivable right to terminate any transfer ${ }^{3}$ of an exclusive right no earlier than 25 years after the execution of the transfer;

ii. extinguish itself five years after it becomes available;

iii. take effect no earlier than twelve months after the creator is notified of the intent to exercise the right;

$i v$ require that notice be subject to registration;

v. $\quad$ require that termination can only be exercised by claimants bolding $51 \%$ or more of the termination right;

vi. provide protection for a transferee ${ }^{4}$ who properly licensed the copyrighted work to create its own authorized original work of authorship.

The recommendation differs from the INDU proposal in three ways. First, the notice period required before termination takes effect is shortened from five years to one year. If a relationship between an author and publisher sours 25 years after rights in the title were assigned (for example, because the publisher

3 As will be discussed in Part 7, the term "transfer" must be defined clearly. The word is used in the U.S. termination statute and is defined to include non-exclusive licenses. Currently, the Canadian reversion statute does not apply to non-exclusive licenses, which remain enforceable after reversion occurs. It is unclear whether INDU is proposing to adopt the U.S. definition and therefore expand the scope of authors' rights in Canada.

4 Id. 
DeMO2 (Do Not DeleTe) 1 1/12/2021 5:41 AM

suddenly takes a book out of print in year 25), an author should not have to wait five years, until year 30, before acquiring rights and republishing the title.

Second, as discussed at length in Section 7(c), current law offers no protection for licensees who create their own original works. For example, a filmmaker will often pay for an exclusive license from a novelist or short story writer prior to making a movie. Giving each qualifying contributor ${ }^{5}$ to a film the right to revoke permission upon reversion and gain substantial control over the film's distribution and revenue stream could distort incentives for those who create such works and could also pose a threat to their continued availability. U.S. law, which is quite similar to the original INDU proposal, protects the creators of derivative works by preserving the terms of the original assignment, even after termination.

The CHPC proposal, which is simpler and easier to implement, is questioned on the grounds that it might increase the orphan works problem and impose greater transaction costs on publishers. As discussed in Section 7(b), the automatic reversion of rights might require the needless renewal of many transfers, even when all parties are satisfied with the original deal struck by the author. ${ }^{6}$ In addition, when authors are deceased and rights revert to disparate heirs, the ownership of works can be difficult to discern and subject to conflicting interests of multiple parties. Publishers might respond to the transaction costs imposed by automatic reversion by routinely ceasing publication after 25 years, except for the most profitable works. ${ }^{7}$

5 Under U.S. law, works specially commissioned for films are works-made-for-hire and not subject to reversion or termination. H.R. REP. 94-1476 at 4, 125 (94th Cong. 1976). So, a set designer, videographer, or scriptwriter hired specially to produce a work for a movie would not be able to assert any rights in their creative contribution. In Canada, the work-forhire doctrine is narrower and basically includes only formal employees. Therefore, a set designer, videographer, or scriptwriter who was an independent contractor, and not an employee, would potentially be able to exercise reversion rights under current Canadian law. As noted in Part 7, infra, this situation provides a further rationale to provide specific protections for the creators of derivative/composite works like films.

6 One could, perhaps, further amend Section 14 to allow for post-reversion exploitation by publishers until they receive notice from a claimant. Such amendment would help the orphan works problem, but it would result in a reversion regime that looks much like a termination scheme.

7 Although this report prefers the adoption of a termination right instead of automatic reversion, it uses the term "reversion" broadly, to describe any system in any jurisdiction that allows creators to regain legal rights in their works. 


DeMO2 (Do Not DeleTE) $1 / 12 / 2021 \quad 5: 41$ AM

\section{BACKGROUND AND METHODOLOGY}

The roots of rules promoting copyright reversion to authors are generally paternalistic, "designed to provide protection for authors against bad deals." The legislative history of the U.S. termination statute makes this equitable motivation explicit: "A provision of this sort [17 U.S.C. \$203] is needed because of the unequal bargaining position of authors, resulting in part from the impossibility of determining a work's value until it has been exploited." 9 The present Canadian statute originates from the 1911 U.K. Imperial Copyright Act which was purportedly passed in response to the impoverished status of Charless Dickens' heirs. ${ }^{10}$

As a legal mechanism with an equitable justification, copyright reversion is viewed as providing private benefits to authors and their estates, but it is potentially in conflict with the public welfare goals of copyright law. For example, a poorly crafted reversionary right might diminish publishers' incentives to invest in new works. However, when reversion is likely to increase both private welfare to authors and public welfare (as appears to be the case in the United States), then adopting a reversion regime is advisable. Whenever a potential conflict between private and public interests is identified, then the rights reversion regime should be crafted to minimize social costs. This study examines the current proposals before Parliament in light of the need to balance the interests of authors and the public.

The primary methodology of this report is cost/benefit analysis, supported by data gathered on the effect of the copyright reversion regimes on book markets in Canada, the United Kingdom, and the United States. Whether markets for other copyrighted works respond in a similar fashion is unclear (although some thoughts on the music market are offered below). Rights

8 See What if We Could Reimagine Copyright? 166 (Rebecca Giblin \& Kimberlee Weatherall eds., 2017) ("Reversionary rights are putatively designed to provide protection for authors against bad deals."); Maria Lill 'a Montagnani \& Maurizio Borghi, Positive Copyright and Open Content Licenses: How to Make a Marriage Work by Empowering Authors to Disseminate Their Creations, 12 Int'l J. COMM. L. \& POL'Y 244, 262 (2007) (referring to reversionary schemes as "legal paternalism"); Pierre B. Pine, "You're Terminated: Termination and Reversion of Copyrights and the Termination Rights Dilemma," MCPherson Rane LLP (July 23, 2014), http://mcphersonrane.com/articles/youre-terminated-termination-and-reversion-of-

copyright-grants-and-the-termination-gap-dilemma ("The purpose and rationale of the termination provisions was clearly equitable in nature, to allow authors or their heirs a second opportunity to share in the economic success of their works."); Shane Valenzi, It's Only a Day Away: Rethinking Copyright Termination in a New Era, 53 IDEA 225, 227 (2013) ("One point of view (the 'authors' rights view) is ... that copyright law must protect authors in some way against 'unremunerative transfers."').

9 H.R. REP. No. 94-1476, at 5741 (1976).

10 Alan J. Hartnick, Stanley Rothenberg: Final Thoughts on the Dickens Provision, 54 J. COPYRIGHT SOC’Y U.S.A. 565, 565, 569 n.1 (2007). 
DeMO2 (Do Not DeleTe) $1 / 12 / 2021$ 5:41 AM

reversion, for example, might be irrelevant in the market for computer programs which typically have no market value 25 years after their creation. The central discussion addresses four issues: the private benefits to authors of rights reversion; the public benefits of rights reversion; the potential private costs to authors of rights reversion; and the potential public costs of rights reversion.

\section{PRIVATE BENEFITS OF Rights REVERSION}

The ability to adjust a contract is the most obvious benefit that rights reversion provides to authors. ${ }^{11}$ Reversion can help ameliorate the effects of a lop-sided deal, like those entered into by musicians Solomon Linda (who sold his rights to "The Lion Sleeps Tonight" for ten shillings ${ }^{12}$ ), Fats Waller (who sold the rights to "Ain't Misbehavin"” for $\$ 500^{13}$ ), and Little Richard (who sold the rights to "Tutti Frutti" for $\$ 50^{14}$ ). More recently, Andrzej Sapkowski, author of the popular "The Witcher" novels, purportedly sold his video game rights for only $\$ 9500$ to a video game company that has since sold at least 33 million copies of "The Witcher" video games. ${ }^{15}$ Of course, embarrassed by these sorts of anecdotes, publishers may be offering better deals. Quantitative data is lacking on the equity of current remuneration trends.

Nonetheless, even when publishers fully embrace fair compensation, remuneration is only one issue relevant to the benefits of rights reversion. Even when royalty schemes are fair, research into common contractual terms offered by publishers reveals problems that could be addressed by rights reversion. The Author's Interest Project (Professor Rebecca Giblin, Project Lead) recently

11 M. William Krasilovsky \& Robert S. Meloni, Copyright Law as Protection Against Improvidence, 5 CoMM. \& L. 3, 5 (1983) ("reversion[ ] and termination provisions of copyright stem from a desire to redistribute the capital asset of copyright to the originator as a protective device against improvident assignments or transfers.").

12 Rian Malan, In the Jungle: Inside the Long, Hidden, Genealogy of 'The Lion Sleeps Tonight', Rolling STONE (May 14, 2000, 3:41 PM), https://www.rollingstone.com/music/musicfeatures/in-the-jungle-inside-the-long-hidden-genealogy-of-the-lion-sleeps-tonight-108274/.

13 Krasilovsky \& Meloni, supra note 11, at 35.

14 Nick Messitte, Five Truly Terrible Record Deals Compiled for Your Convenience, ForBES (April 30, 2015, 12:20 PM), https://www.forbes.com/sites/nickmessitte/2015/04/30/five-trulyterrible-record-deals-compiled-for-your-convenience/\#1a9f41ee5a35. See generally RusSELL C. Brennan, Music Business Bastards (Avril Eglinton ed., 3d ed. 2013).

$15 @$ webdeals, Andrzej Sapkowski sold bis copyright for only 9.5k dollars, STEEMIT.COM (2017), https://steemit.com/game/@webdeals/andrzej-sapkowski-sold-his-copyright-for-only-9-

5k-dollars. PC Gamer Magazine reports that Sapkowski and CD Projekt, who produced the video game, have since come to a percentage deal. Andy Chalk, CD Projekt has a new deal with The Witcher creator Andrez Sapkowski, PC GAMER (Dec. 20, 2019), https://www.pcgamer.com/cd-projekt-has-a-new-deal-with-the-witcher-creator-andrezsapkowski/. 
DeMO2 (Do Not DeleTE) $1 / 12 / 2021 \quad 5: 41$ AM

analyzed almost 60 years of Australian publishing contracts ${ }^{16}$ and came to several important conclusions. The preliminary results of the research showed that 14\% of contracts failed to address authors' rights when books went out of print. In fact, only $6 \%$ provided that unexploited rights would be returned to authors, and the vast majority of contracts were lacking any objective criteria defining out-ofprint status. Other important terms were frequently left out, including foreign language rights and the duration of the contract. Perhaps most disturbing was the finding that most contracts took exclusive rights for the entirety of the copyright term. In a jurisdiction like Canada, a publishing contract can last upward of 100 years (for example, a book contract entered into by a 25 -year-old who lives to be 90 would not be subject to reversion for 100 years). The authors of the study were troubled by the compatibility of long contracts with technological change: "What will books look like in 2150? What will publishers look like? What will be the opportunities and challenges for authors, publishers, and society at large? We can't possibly expect the drafters of publishing contracts to accurately predict those things." 17 Reversion can allow for efficient contract adjustments.

The Author's Alliance, ${ }^{18}$ a U.S. advocacy group for authors, has also collected sample publishing contracts but has not completed a formal empirical analysis. In response to my query, they were able to provide further examples of publisher over-reaching. For example, some publishers of textbooks and journal articles use standard contracts claiming all rights, including translation rights in countries where the publisher has no intent to exploit the work and including movie rights! In one contract, a university press claimed to take all "operatic" rights to a scholarly work. Another contract commits an author to offer their next book to the publisher under "the same terms and conditions" as the first book. Publishing contracts are, for the most part, forms offered on a "take it or leave it" basis, which provides few disincentives for overreaching or for carefully redrafting contracts to better encompass technological change or the parties likely real intent.

Giving authors or their estates the right to terminate a contract after 25 years provides an opportunity to address some of the issues (remunerative and non-remunerative) discussed above. The contract can be renegotiated or amended, or a new publisher can be identified. Most importantly, even if an initial contract was generally fair, termination can provide an opportunity for an

16 Rebecca Giblin, Are authors' rights 'all taken care of' by their contracts? Our newresearch suggests not, AUTHOR's INTEREST (Oct. 15, 2019), https://authorsinterest.org/2019/10/15/areauthors-rights-all-taken-care-of-by-their-contracts-our-new-research-suggests-not/.

17 Id.

18 See About Us, AutHORS AllianCE, https://www.authorsalliance.org/about/ (last visited Oct. 8, 2020) (describing the mission of the Authors Alliance). 
Demo2 (Do Not DeleTE) 1 1/12/2021 5:41 AM

author to bring a work back into print or to create a new derivative work based on the original without seeking permission.

\section{PubliC BENEFITS OF RightS REVERSION}

The primary public benefit of rights reversion is the measurable increase in the availability of works to the public when copyright ownership reverts from original publishers to back to authors or their estates. As explained below, this benefit is particularly important in Canada because it may help to partially offset the enormous cost to the public of copyright term extension under the proposed United States-Mexico-Canada Agreement. This section will first summarize the empirical data that shows how term extension (and long copyright terms in general) diminishes the availability of books (section 5(a)) and increases book prices (section 5(b)). Then, it will summarize the data that shows how rights reversion to authors can bring books back into print (section 5(c)) to help offset the public welfare losses caused by long copyright terms.

\section{A. NEGATIVE EFFECTS OF TERM EXTENSION ON BOOK AVAILABILITY}

The negative effect of copyright term extension on the availability of books (measured by "in-print" status) and on book pricing has been well-documented in the United States ${ }^{19}$ and the present study for the first time reports data from Canada and the U.K. that are consistent with the U.S. experience. The effect of long copyright terms in the United States is summed up in the graph below which presents a random sample of new editions of books on Amazon arranged by the decade of initial publication. ${ }^{20}$

19 Paul Heald, Kristofer Erickson \& Martin Kretschmer, The V aluation of Unprotected Works: A Case Study of Public Domain Images on Wikipedia, 29 HARv. J.L. \& TECH. 1, 2-4 (2015); Paul J. Heald, How Copyright Keeps Works Disappeared, 11 J. EMP. LEGAL STUDs. 829, 829-831 (2014); Christopher Buccafusco \& Paul J. Heald, Do Bad Things Happen When Works Enter The Public Domain?: Empirical Tests of Copyright Term Extension, 28 BERKELEY TECH. L.J. 1, 2-5 (2013); Paul J. Heald, Property Rights and the Efficient Exploitation of Copyrighted Works: An Empirical Analysis of Public Domain and Copyrighted Fiction Bestsellers, 92 MinN. L. REV. 1031, 1031-1034 (2008) [hereinafter Efficient Exploitation]; Xing Li, Megan MacGarvie, \& Petra Moser, Dead poets' property-how does copyright influence price?', 49 RAND J. ECON. 181, 181-184 (2018); Imke Reimers, Copyright and Generic Entry in Book Publishing, 11 Am. ECON. J.: Microeconomics 257, 257-260 (Aug. 2019); Barbara Biasi \& Petra Moser, Effects of Copyrights on Science 2-6 (Dec. 10, 2018) (unpublished manuscript), https://ssrn.com/abstract $=2542879$.

20 See Paul J. Heald, How Copyright Keeps Works Disappeared, 11 J. EmP. Legal Studs. 829, 839 (2014) (employing the same method of analysis). 
Figure 1: Random Sample of New Editions of Books on Amazon.com (2011)

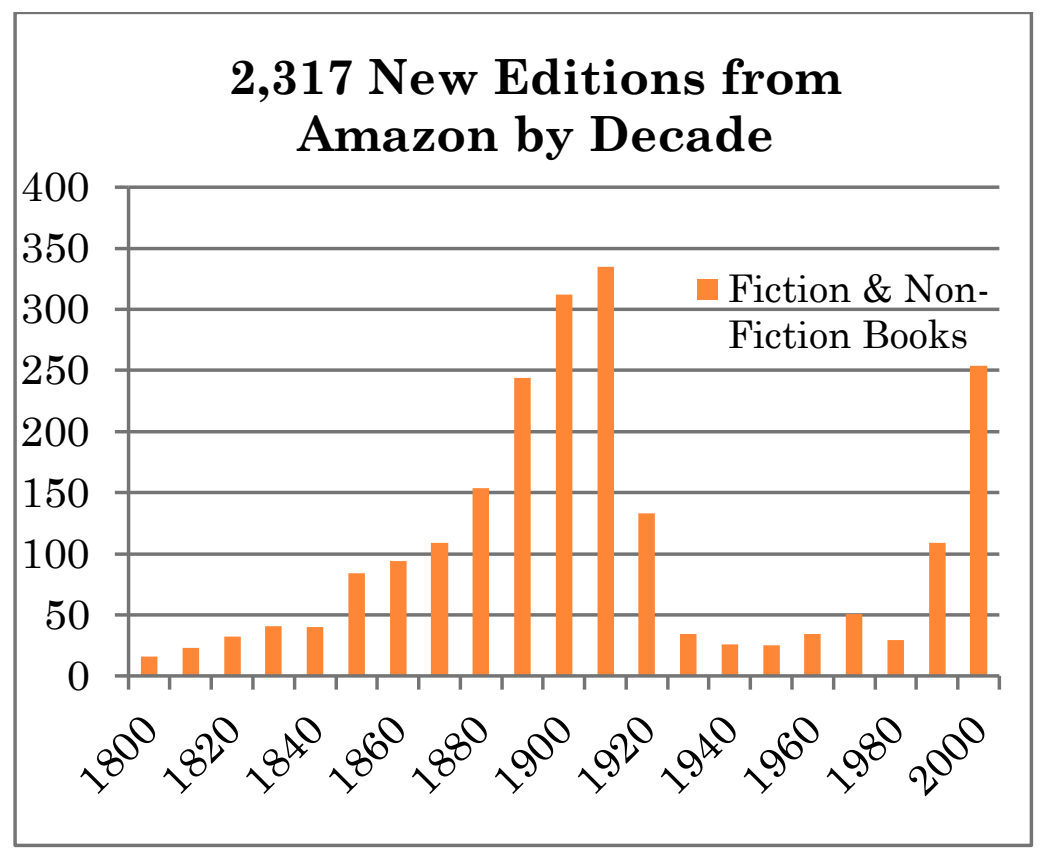

The distortion caused by the term ${ }^{21}$ of copyright protection in the United States is demonstrated by the spike in availability of pre-1923 works, all of which were in the public domain in 2011 when the sample was taken. Pre-1923 works unprotected by copyright were disproportionately represented in the sample; post-1922 works still under copyright fell out of print, and new editions disappeared (except for the most recent titles from 2000-2010).

Long copyright terms also keep works locked up and out of the public eye in the U.K. The graph below depicts the in-print rate for a sample of 2,687 books by 83 prominent U.K. authors who died between 1920-1994.22 The U.K. term of protection is life-of-the-author plus 70 years.

21 The United States adopted life-plus-fifty in 1976, so the public domain books represented in the chart were governed by the former 75 or 95 -year rules of protection. 17 U.S.C. $\int 302$ (1998).

22 The sample was initially collected from the Wikipedia page listing English writers, see https://en.wikipedia.org/wiki/List_of_English_writers. With the exception of Elizabeth Goudge, Alistair Maclean, and Graeme Greene (each a bestselling author), only authors from the Wiki list who also had an entry in the Oxford Companion to English Literature were included in the final sample. 
Demo2 (Do Not DeleTE) 1 1/12/2021 5:41 AM

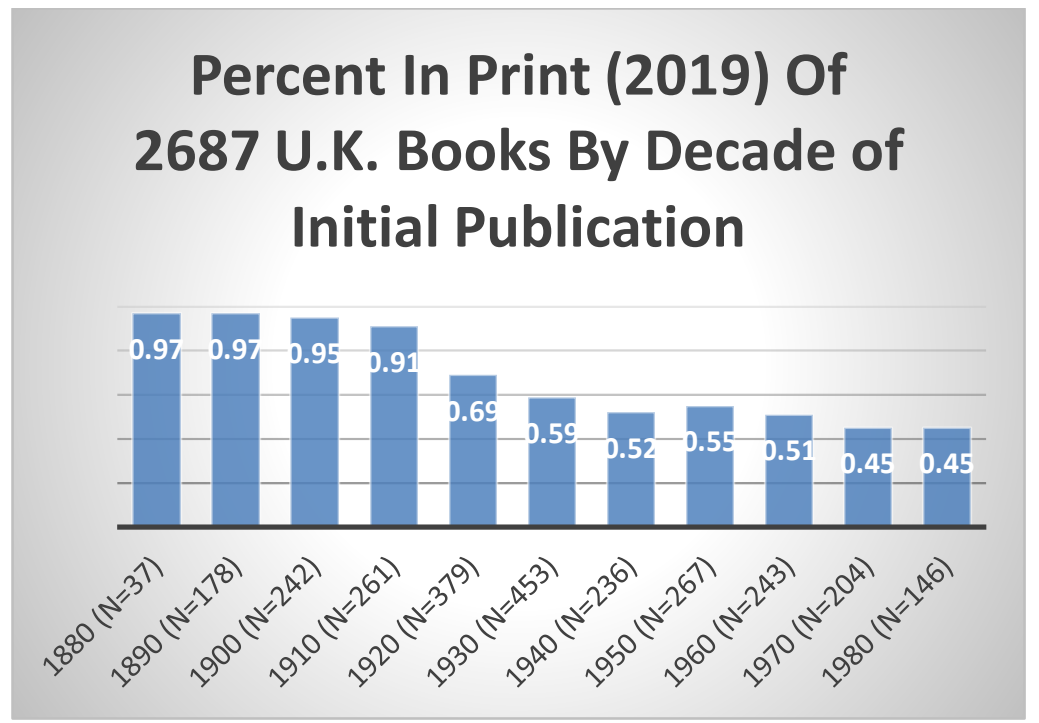

As in the U.S. sample, we see older books (most in the public domain) being significantly more available than newer books still protected by copyright. Books from the 1880s and 1890s are twice as likely to be in print than works from the 1970 s and 1980s. ${ }^{23}$ The pattern of disappearing books is especially dramatic because, unlike the U.S. data that presented a purely random sample containing many obscure titles, the U.K. books were written by authors significant enough to merit an entry in The Oxford Companion to English Literature.

The current situation in Canada, which has a shorter copyright term than the U.K., reflects the same pattern of disappearing books in the twentieth century. ${ }^{24}$ The graph below depicts a sample of 135 Canadian authors, ${ }^{25}$ writing in English and French, who died between 1841-2008. As in the U.K. and the United States, older works published before 1920 are two-to-three times more likely to

23 Overall, public domain books by the sample of U.K. authors were in print at a rate of $83 \%$ for bound volumes and $74 \%$ for e-books. The copyrighted books were in print at a rate of $55 \%$ for bound volumes and $48 \%$ for e-books.

24 This section presents new findings, not yet submitted for publication. Excel spreadsheets containing the relevant data are on file with Canadian Heritage.

25 The authors were identified from the Wikipedia "List of Canadian Writers." "List of Canadian writers." Wikipedia, the Free Encyclopedia, at http://en.wikipedia.org/wiki/List_of_Canadian_writers (last visited Oct. 9, 2020). 
Figure 3: In-Print Rates of Works by Canadian Novelists

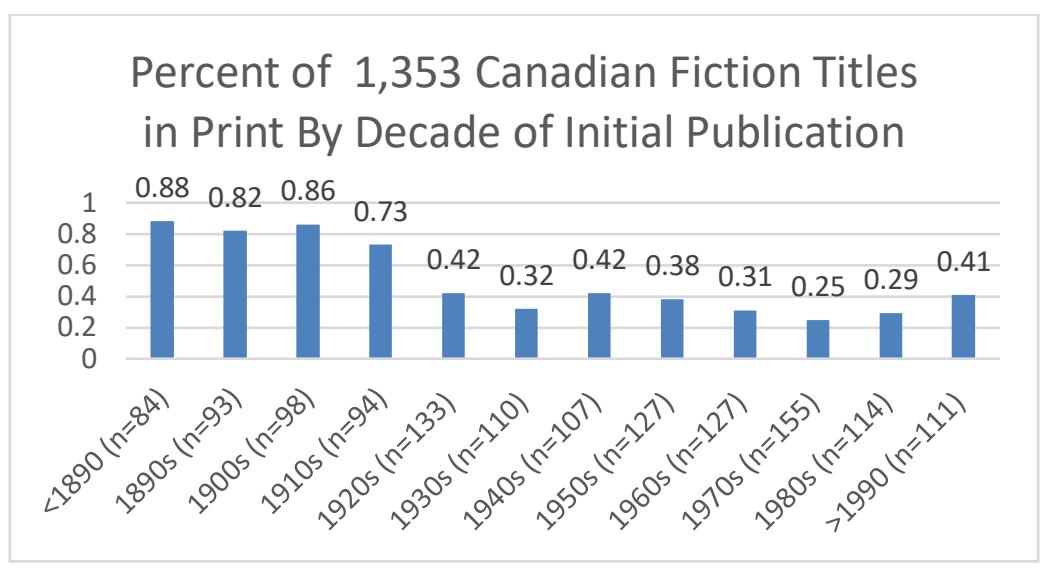

be in print than books published in the 1970s, 1980s, or 1990s. In Canada, as in the United States and U.K., when a book falls into the public domain, it is significantly more likely to be in print. If we sort out the Canadian books into just two groups, public domain books versus copyrighted books, in 2019, the inprint rate is $65 \%$ for the public domain sub-set and only $31 \%$ for the copyrighted subset.

If Canada extends its copyright term from life-plus-fifty to life-plus-seventy, then the public domain will be frozen for 20 years, and the suppression of publication rates for copyrighted titles shown above will be exacerbated. Term extension would significantly deepen the problem of the "disappeared" books from the twentieth century to the detriment of Canadian readers and Canadian heritage.

\section{B. EFFECT OF TERM EXTENSION ON BOOK PRICES}

Lengthy copyright terms affect the availability of books to the public and impose high direct costs in the form of higher book prices. Simply put, books become cheaper when they enter the public domain for two primary reasons. First, the publisher need not pay a royalty to the copyright owner, but more importantly, the market for public domain books is more competitive, with multiple publishers often offering the same title. Competition drives down prices.

For example, a sample of 96 U.S.-bound volumes sold by Random House under its Penguin Classics imprint (48 in the public domain and 48 still under 
DeMO2 (Do Not DeleTe) $1 / 12 / 2021$ 5:41 AM

copyright) showed that the copyrighted volumes were $50 \%$ more expensive. ${ }^{26} \mathrm{~A}$ sample of bound volumes available in South Africa showed a similar price premium paid for copyright titles as compared to their public domain counterparts. ${ }^{27}$ A much larger sample of 1518 public domain and copyrighted ebooks in the U.K. shows an even greater price discrepancy - an average price of $£ 1.3$ for public domain e-book titles and $£ 4.34$ for e-books of copyrighted titles. $^{28}$

Data collected on books sold in Canada show a similar pattern. ${ }^{29}$ A sample of bound volumes of Vintage Classics sold by Random House Canada shows an average $50 \%$ higher price per page for copyrighted classics compared to those in the public domain. ${ }^{30}$ The difference in comparative book pricing in the same sample is even more dramatic for digital editions: $\$ .015 /$ page for public domain e-books and \$.039/page for copyrighted e-books. A much larger sample of 534 novels by Canadian authors confirms the dramatic price difference between public domain and copyrighted e-books. ${ }^{31}$ The average price of 432 public domain e-books was $\$ 1.89 \mathrm{CDN}$, while the average price for 102 copyrighted titles was over $\$ 11 \mathrm{CDN}$.

If Canada extends its term of copyright, then the public domain will be frozen for 20 years and Canadian consumers will continue to pay much higher prices for titles that would have fallen out of copyright. Crucially, this cost would be imposed with no offsetting benefit to the public. It functions as a tax in favor of publishers, for which the publishers need to offer no quid pro quo because the books already exist. Importantly, letting the books fall into the public domain does not threaten copyright's core rationale to provide adequate incentives for authors to create. Term extension for existing works provides no creative incentives, but rather only reduces availability while increasing prices.

26 See Efficient Exploitation, supra note 19, at 1049. The average price of the 48 copyrighted titles was $\$ 14.60$, with an average length of 310 , resulting a price of $\$ .047$ per page. The 48 public domain volumes' average price was $\$ 11.22$, with an average length of 374 pages, resulting in an average price of $\$ .030$ per page.

27 Paul J. Heald, The Effect of Term Length on South African Book Markets (with Reference to the Google Book Project), 6 J. OF S. AFr. InTELL. Prop. L. 1, 16 (2020).

28 These are new findings, not yet submitted for publication. Excel spreadsheets containing the relevant data are on file with Canadian Heritage.

29 Id.

30 The 41 public domain books in the sample were being offered by Random House Canada for an average price of $\$ 6.76 \mathrm{CDN}$, with an average length of 451 pages, resulting in an average price per page of $\$ 0.015$. The 49 copyright books in the sample were being offered for $\$ 12.53$, with an average length of 322 pages, resulting in an average price per page of $\$ 0.039$ CDN.

31 This sample consists of all the books by Canadian authors depicted in Figure 3 published in e-book editions. 
DeMO2 (Do Not DeleTE) $1 / 12 / 2021$ 5:41 AM

\section{RIGHTS REVERSION INCREASES THE AVAILABILITY OF BOOK TITLES}

Under U.S. law, an author or the author's estate can terminate a post-1978 assignment of copyright 35 years after the assignment. ${ }^{32}$ Since the proposal endorsed in this report (except for the termination time term) tracks the U.S. statute, data from the United States is pertinent. In fact, any public benefit derived from the 35-year U.S. termination right might be amplified in Canada, were it to adopt a shorter 25-year term. The summary below includes data collected on reversion under U.K. and Canadian law and the U.S. regime for pre1978 works (which provides for termination at year 56 after publication). ${ }^{33}$

In order to study the effect of copyright reversion rules on the availability of books in the United States, I collected data on book titles in three categories: 1) 819 novels written by 60 authors who died between 1973 and 1999 and who had at least one book on an end-of-year New York Times (NYT) bestseller list; 2) 268 novels from 1956-59 and 1963-66, and 421 novels published between 197481 and 1983-86, that spent at least one week on the NYT bestsellers list; and 3) 464 books (non-fiction and fiction) reviewed in the NYT Book Review from 1978-1984. ${ }^{34}$ The dates in each sample were chosen to generate a mix of books eligible and ineligible for reversion under the rules governing the termination of copyright transfers for U.S. works (35 years after transfer for post-1978 works or 56 years after publication for pre1978 works). The sample universes were chosen to create a mix between bestselling and non-bestselling books and between fiction and nonfiction titles.

In the absence of an easy method of determining when a U.S. termination right has been exercised, 35 the study gathered publication histories of 1033 of the books that were in print in 2017 from Amazon.com. ${ }^{36}$ The study categorized each book as being in print with a major publisher (usually the original transferee), denominated below as

32 See 17 U.S.C. $\$ 203$ (2002).

33 See 17 U.S.C. $\$ 304$ (2002).

34 See Paul J. Heald, Copyright Reversion to Authors (and the Rosetta Effect): An Empirical Study of Reappearing Books, 66 J. COPYRIGHT SOC'Y U.S.A. 59 (2019) [hereinafter Copyright Reversion to Authors]. U.K. and Canadian data have only been collected recently and are on file with Canadian Heritage.

35 See id. at 93-94. In theory, a claimant seeking to terminate a transfer under 17 U.S.C. $\$ S$ 203 or 304 must provide notice to the transferee and then file a notice of termination with the U.S. Copyright Office. In practice, few claimants make the filing and pay the fee. Once the original transferee has acquiesced in writing to the notice of termination, claimants apparently see little reason to file make a filing.

36 Although Bowker's Books-in-Print also provides data on all books with an ISBN identification code, Amazon's record of in-print books bearing ISBN numbers is practically as complete and, in addition, lists the status of tens of thousands of books identified only by an ASIN number. 
Demo2 (Do Not DeleTE) 1 1/12/2021 5:41 AM

"PUB," or as being in print with an independent publisher (almost all less than 15 years old), denominated below as "IND." Within each category, the study identified books as being in print as both an e-book and a bound volume (e/b), in print only as a bound volume (b), or only in print as an e-book (e). Publication details served as evidence that a termination right had been exercised.

The copyrights in books still in print in 2017 with their original publisher (or any large traditional publisher like Random House, Hachette, Macmillan, Simon \& Schuster, Harper Collins, or Houghton Mifflin) were deemed not to have been terminated. This assumption almost certainly resulted in an undercount of termination activity because publishers might have responded to a termination notice by bringing a book back into print. The study's methodology also assumed that the termination right had no effect on the in-print rates of books that were technically ineligible for reversion, which might also undercount the effect of a termination threat. Under U.S. law, the notice of termination can be sent to a publisher up to ten years before the earliest termination date. ${ }^{37}$ An early notice may well prompt a publisher to relinquish rights to the author or its estate who then finds a new publisher to bring the book back into print (or self-publish) during a time period when the book is technically ineligible for termination. Indeed, the study found significant evidence of new, independent publishers making books available during time periods when the original publisher could, in theory, control the copyright and keep the book out of print. ${ }^{38}$ These publications may be in print due to a termination "nudge."

The study's methodology assumed that titles brought back into print by an independent publisher after the work became eligible for termination were in print through the operation of a reversion rule. The study found no evidence that independent presses were buying copyrights from original publishers; instead, the business models of the independent presses were often expressly described as taking advantage of U.S. reversion rules. Open Road Media, the independent press publishing the plurality of titles, stated:

We are committed to bring back the backlist, making reverted titles and works that have never been converted to digital format widely available as e-books .... This program is for authors whose rights have reverted, whose

37 See 17 U.S.C. $\$ 304(\mathrm{c})$.

38 See Copyright Reversion to Authors, supra note 34, at 126. Figure 7 shows that of 121 termination ineligible books published between 1963-66, 33\% were being published by new independent presses. 


DeMO2 (Do Not DeleTE) $1 / 12 / 2021 \quad 5: 41$ AM

titles have not previously been digitized, or who are looking to have their works available as e-books. ${ }^{39}$

As the quote suggests, Open Road obtains rights from authors and estates, not from other publishers. A number of other prominent independent publishers of e-books follow a similar model, intentionally targeting books that major publishers are no longer making available. ${ }^{40}$

The assumption that authors or their estates are taking advantage of reversion when an out-of-print, reversion-eligible book is brought back by an independent press may result in overcounting. For example, one cannot observe contractual terms which might allow some authors to regain a copyright from an original publisher after a book goes out of print. ${ }^{41}$ More importantly, as discussed below, the 1982 Random House $v$.

39 See Paul Heald, Readers and Book Markets Benefit from Authors Reclaiming Their Rights, Authors Alliance (Apr. 3, 2018), https://www.authorsalliance.org/ 2018/04/03/readers-and-book-markets-benefit-from-authors-reclaiming-their-rights (quoting the former Open Road Media website).

40 See About Us, Mysterious Press (last visited Jan. 16, 2019), http://mysteriouspress.com/about-us ("The books offered by MysteriousPress.com are currently out of print but protected by copyright, and will take advantage of digital reading formats to bring classic fiction to new audiences."); About Us, ROSETTA BOOKS (last visited Jan. 16, 2019), https://www.rosettabooks.com/about-us (noting that the company launched in 2001 and today the company's 800-plus title list includes classic e-books of every category); About Us, CrossroAD Press (last visited Jan. 16, 2019), http://crossroadpress.com/about (The original intent was simply to bring my own out of print books to Kindle and other eReaders .... We are now a growing, widely distributed digital publishing company [with] . . over 1600 titles"); About, ENET PRESS (last visited Jan. 16, 2019), https:/ / www.enetpress.com/\#!/about ("eNet Press was created by the sons of C.S. Forester-John and George Forester in 2011. Their first effort was to publish all 12 volumes of the Hornblower Saga." Today, eNet Press focuses on publishing the works of other great authors, such as: Taylor Caldwell, John Collier, Richard Bissell, Samuel Shellabarger and Thorne Smith to name a few.); Our History, VALANCOURT BOOKS (last visited Jan. 16, 2019), http://www.valancourtbooks.com/our-history.html ("Valancourt Books is an independent small press specializing in the rediscovery of rare, neglected, and out-ofprint fiction."); e-book Store, JABBERWOCKY LITERATURE AGENCY (last visited Jan. 19, 2016), http://awfulagent.com/ebooks ("JABerwocky has partnered with many of our clients to release ebook editions of their works."); Estates, WILDSIDE PRESS (last visited Jan. 19, 2019), http://wildsidepress.com/estates (listing estates represented by the press); see also Home, GreAt NORTHERn BOOKS (last visited Jan. 16, 2019), https://www.gnbooks.co.uk ; Home, House OF STRATus (last visited Jan. 16, 2019), http:/ /www.houseofstratus.com; About, FIFTH STAR PrESS (last visited Jan. 16, 2019), https: / / fifthstarpress.wordpress.com; and About Us, ODYSSEY PRESS (last visited Jan. 16, 2019), http://www.theodysseypress.com/about-us.

41 Most of the titles were out of print for a significant amount of time before being brought back into print which suggests that reversion via contract is probably not doing much work. 
Rosetta Books ${ }^{42}$ decision complicates interpretation of the data gathered on reversion-eligible titles brought back into print by independent publishers.

Figure 4: Publishers of NYT Bestsellers

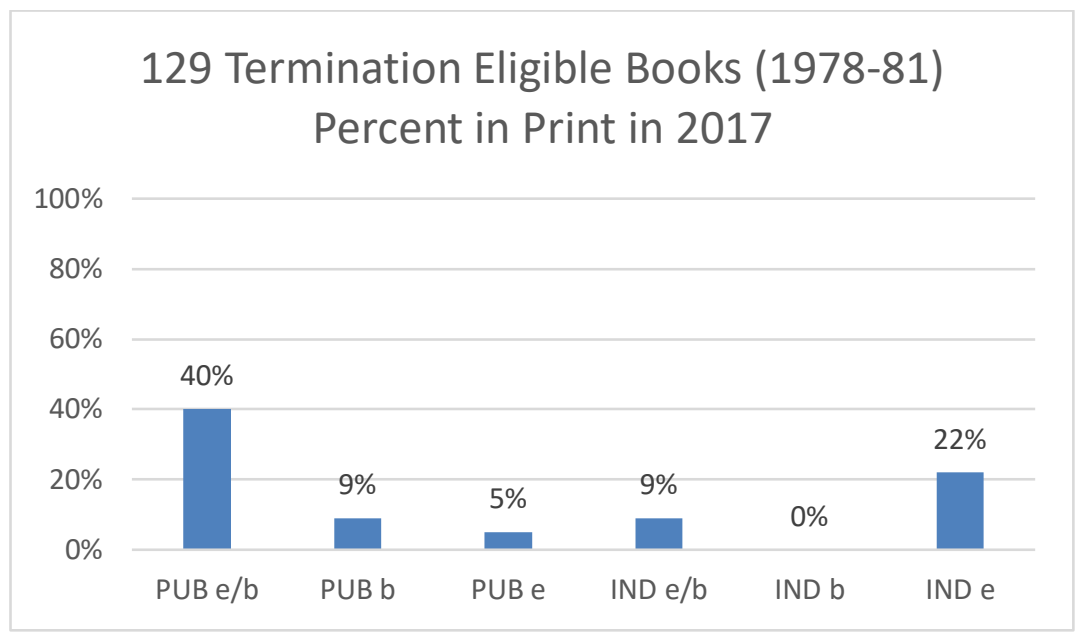

The graph above shows that $31 \%$ of bestsellers initially published between 1978-81 and eligible for reversion between 2013-2016, were published by independent presses like Open Road Media, suggesting a significant number of authors or their estates are taking advantage of the 35 -year termination right. However, some of solo e-books $(22 \%$ of the in-print titles) may be printed by the operation of the decision in Rosetta Books ${ }^{43}$ which worked a de facto reversion of digital rights to some authors. Rosetta Books held that authors with contracts similar to Kurt Vonnegut and Thomas Stryon had not signed away their digital rights in contracts with Random House. ${ }^{44}$ As a result, an unknown number of authors suddenly regained their e-book rights in 2002. Since the opinion left the publishing rights to bound volumes with the original transferee, publication of a title as a solo e-book in the data set may have resulted by operation of Rosetta Books rather than by a statutory termination right. Without interviewing hundreds of authors or their estates, it's impossible

42 Random House, Inc. v. Rosetta Books L.L.C. , 150 F. Supp. 2d 613 (SDNY 2001), aff'd 283 F.3d 490 (2d Cir. 2002).

43 Rosetta Books, 150 F. Supp. 2d 613.

44 The contracts provided that the authors had transferred all rights to their stories "in book form." The court surprised the literary world by holding that an e-book was not "in book form." See Copyright Reversion to Authors, supra note 34, at 75-79. 
to pinpoint precisely the motivating factor behind the reappearance of an e-book-only title. Of course, one can assume that many authors taking advantage of Rosetta Books would also have used the termination right when it became available.

With these caveats in mind, Figures 5 and 6 below depict in-print rates for two further classes of titles that were eligible for reversion by 2017. The graphs also suggest that in-print rates for all books are sensitive to the popularity and to age of the titles.

Figure 5: Publishers of Books Reviewed in the NYT Book Review

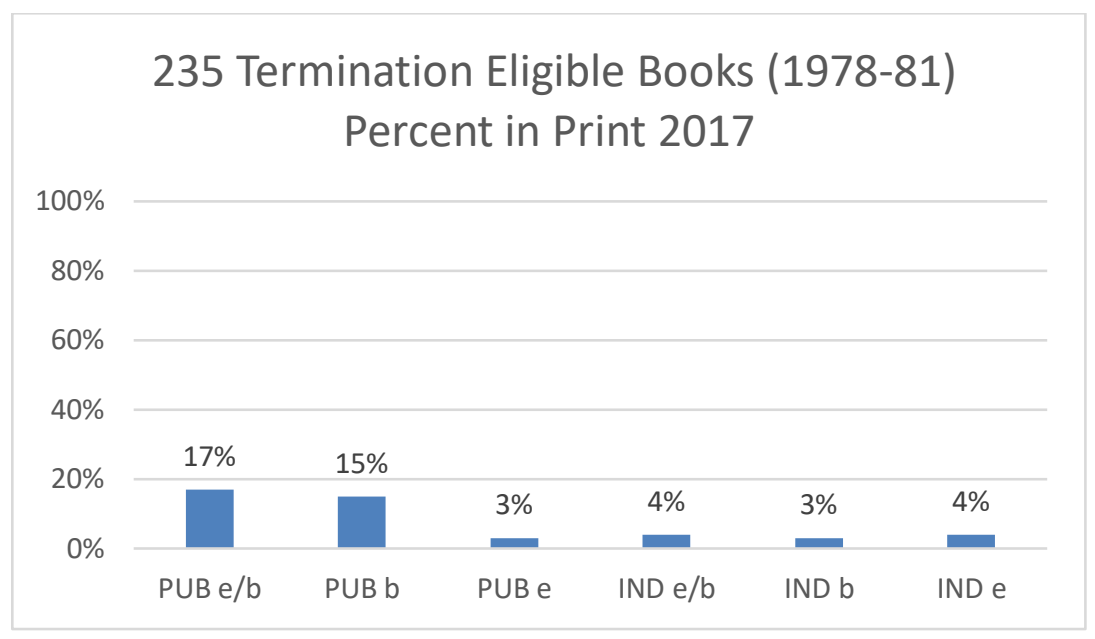

Very few of the 235 titles in Figure 5 were bestsellers. The NYT reviews a wide variety of academic titles, popular non-fiction, histories, biographies, and literary fiction, so perhaps it is not surprising that only $46 \%$ of the titles were in print in 2017 , with $11 \%$ published by independent presses or self-published. 
DeMO2 (Do Not DeleTE) $1 / 12 / 2021 \quad 5: 41$ AM

Figure 6: Publishers of Books by Authors with at least one NYT Bestseller

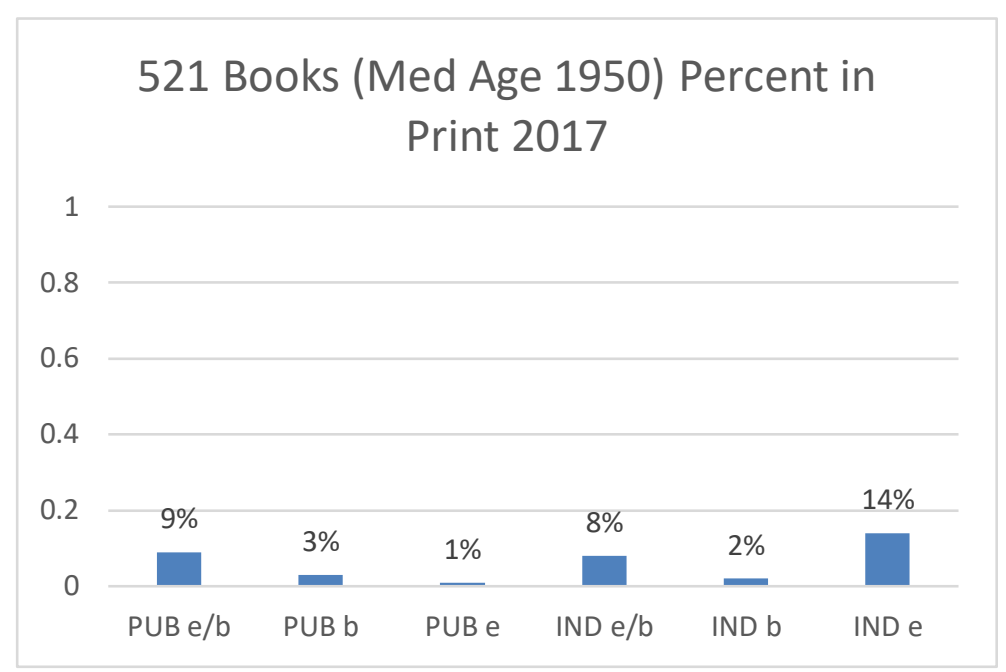

The titles in Figure 6 are significantly older than the titles in Figure 4, which may explain why the in-print rates are lower. In addition, as pre-1978 titles, they are subject to termination in year 56 after publication, which is a significantly longer period than the 35-year termination rule governing the titles in Figures 4 and 5. The longer wait for the termination right to vest may result in coordination problems with heirs, and the passage of time definitely reduces the value of most titles, making them less attractive targets for republication.

Overall, a summing of the data presented in the three graphs above shows that $23 \%$ of the 885 termination eligible titles were in print in 2017 by new, independent presses, suggesting that many are in print due the operation of the 35-year or 56-year termination rules. As noted above, an unknowable percentage may instead by in print because of Rosetta v. Random House.

The U.K. and Canada both have reversion statutes that provide for rights reversion to authors' estates 25 years after the death of the author. In the U.K., the rule applies only to books published before 1958.45 Using a methodology similar to that used to study U.S. books, I identified 44 prominent U.K. authors who died between 1980-1994 and collected publication data on 492 of their novels and short story collections published before $1958 .{ }^{46}$ Of those titles, 9\% were brought back into print by an independent press and made newly available

45 Rosina Harris, Reversionary Rights in the United Kingdom and Canada, 30 J. COPYRIGHT SOC'Y U.S.A. 544, 545 (1983).

46 These are new findings, not yet submitted for publication. Excel spreadsheets containing the relevant data are on file with Canadian Heritage. 
DeMO2 (Do Not DeleTE) $1 / 12 / 2021$ 5:41 AM

25 years or more after the author's death. A good example would be a title by George Barker (1913-1991), The Seagull, which was republished by the Abandoned Bookshop in 2016. ${ }^{47}$

Although the Canadian rights reversion statute ${ }^{48}$ applies to all titles by eligible authors, regardless of publication date, the number of books by Canadian authors appearing to be in print because of reversion in Canada is only slightly higher than in the U.K. A study of 41 Canadian authors who died between 19771992 and 288 of their novels and short story collections, found that an independent press brought $10.4 \%$ of the titles back into print 25 years or more after the author's death. ${ }^{49}$ Interpretation of this data is slightly clouded by the fact that sometimes Canadian copyrights revert to authors early when a publisher declares bankruptcy, ${ }^{50}$ but the current Canadian reversion statute is surely doing some work, although its impact appears, not surprisingly, to be much less than in the United States.

Rights reversion and termination statutes may have their roots in a paternalistic view of the bargaining power of young authors, ${ }^{51}$ but in reality, transferring copyrights back to authors appears to serve the public purpose of bringing out-of-print titles back to life for consumers. ${ }^{52}$

\section{A NOTE ON MUSIC}

A variety of data accessibility problems complicate the study of copyright reversion in the context of musical compositions. Unfortunately, there is no Amazon.com, Books-in-Print, or any comprehensive database that tracks the historic availability of musical compositions. Nonetheless, a search of the U.S. copyright office database shows that some Canadian songwriters have been taking advantage of the U.S. termination statute to reclaim their U.S. copyrights. Of 29 Canadian songwriters active from 1978-84 (years subject to the U.S. 35year termination right), ten had filed at least one notice of termination. In total, the copyright transfers of 864 songs were terminated by Canadian songwriters

47 The DeAD SeAgulL, https://www.abandonedbookshop.com/books/dead-seagull/ (last visited Sept. 27, 2020).

48 Copyright Act, R.S.C. 1985, c C-42, s. 14, par. 1.

49 These are new findings, not yet submitted for publication. Excel spreadsheets containing the relevant data are on file with Canadian Heritage.

50 Bankruptcy and Insolvency Act, R.S.C. 1985, c B-3. s. 83, par. 1.

51 Interestingly, the first copyright law, the Statute of Anne (1710), Section 11, had a reversion-type function that gave surviving authors back their rights after 14 years (for 14 more years). It's possible that this was an anti-monopoly measure aimed at the Stationer's Company rather than being driven by paternalistic concerns. 8 Anne, c. 19 (1710).

52 It is unclear whether the effect is as strong in markets where it is cheaper and easier than books for publishers to make older works available. For example, old vinyl recordings are easy to convert to .mp3 format to sell on itunes. Reversion to composers may therefore have a less dramatic effect. 
Demo2 (Do Not DeleTE) 1 1/12/2021 5:41 AM

such as Bryan Adams, Robbie Robertson, Randy Bachman, Neil Young, Joni Mitchell, Paul Anka, Rik Emmet, Mike Levine, Mark Gane, and Frank Merino. 53 Assessing the public benefit of this activity is difficult. Because U.S. copyright law provides for the compulsory licensing of musical compositions for recording, rights reversion should have little effect on the number of recordings commercialized. The termination right, however, would usually give composers or their estates control over the creation of new derivative works, such as new musical adaptations and synchronizations. In addition, if the composer is sharing streaming royalties with its music publisher, the composer may be able to capture a greater percentage of all streaming revenue from outlets like Spotify or Pandora (a private benefit).

\section{Private Costs of Rights Reversion}

The argument that rights reversion could backfire and harm authors stems from the concern that publishers will offer diminished compensation to acquire rights that are subject to termination long before the end of their copyright term. The question can be neatly articulated in terms of a private cost to authors: Will publishers compensate Canadian authors less for rights that will last 25 years instead of life-of-the-author plus 25 years?

The short answer is "no." Under a wide range of assumptions about depreciation rates for copyrighted works and predictions of applicable discount rates, publishers earn the vast majority of profits during the first 25 years of the life of a copyright. Although from an ex post perspective, the occasional rare work will maintain value for a longer time, a rational publisher making an ex ante judgment is unlikely to offer a Canadian author diminished compensation if a 25 -year reversion or termination right were to be adopted. In fact, as discussed below, the possibility that a massively popular work will maintain its value is fully accounted for when calculating average anticipated earnings (which is what publishers rely on).

When considering what contractual terms to offer, publishers must consider the net present value of the rights for which they are bargaining. In other words, how much will the publisher be likely to earn over the course of the contract? In a world where the length of an assignment is capped at 25 years, a publisher must determine how much it is likely to earn over the limited term. In response, a lump sum or, more much more likely, an ongoing royalty will be offered to the author. If a publisher would, hypothetically, only earn $50 \%$ of the value of the copyright by year 25 , then it would rationally offer less than it would for a contract enforceable for 50-80 years.

53 Interestingly, other prominent Canadian songwriters have not used the termination process to reclaim their U.S. copyrights, e.g. Gordon Lightfoot, Burton Cummings, and Leonard Cohen. 
A publisher's decision can be modeled under a number of differing assumptions. ${ }^{54}$ Two choices are critical. First, an assumption about the rate of depreciation of the work must be made. According to a U.S. National Bureau of Economic Research (NBER) study, the average yearly depreciation rate for books is $12 \% .55$ Another NBER study suggests the rate of depreciation for music is even steeper. Songs are reported to depreciate 65\% during their first year, which means that most profits are taken within the first five years of sales. ${ }^{56}$ Albums are reported to depreciate at an average rate of approximately $26 \% .57$ Second, a discount rate must be chosen to reflect the time value of money based on historic lending rates. Since discount rates have varied substantially over time, from $1 \%$ to $15 \%$ or more, Figure 7 below provides assumptions from $2 \%$ to $7 \%$, a range that captures a wide range of historic averages over the last 50 years.

In Figure 7, the vertical column employs varying assumptions as to potential discount rates and the horizontal row provides a range of depreciation assumptions from $10 \%$ to $26 \%$. One can see quite quickly that at the time of contracting, rational publishers assume that they will earn the vast majority of their profits by year 25 .

Figure 7: Percent of Present Value of Asset Earned by Year 25

\begin{tabular}{|c|c|c|c|c|c|c|c|}
\hline $\mathrm{r} / \mathrm{d}$ & $10 \%$ & $12 \%$ & $14 \%$ & $16 \%$ & $18 \%$ & $20 \%$ & $26 \%$ \\
\hline $2 \%$ & $94.40 \%$ & $96.40 \%$ & $97.70 \%$ & $98.50 \%$ & $99.00 \%$ & $99.40 \%$ & $99.81 \%$ \\
\hline $3 \%$ & $95.60 \%$ & $97.20 \%$ & $98.20 \%$ & $98.80 \%$ & $99.20 \%$ & $99.50 \%$ & $99.85 \%$ \\
\hline $4 \%$ & $96.50 \%$ & $97.80 \%$ & $98.60 \%$ & $99.10 \%$ & $99.40 \%$ & $99.60 \%$ & $99.88 \%$ \\
\hline $5 \%$ & $97.30 \%$ & $98.30 \%$ & $98.90 \%$ & $99.30 \%$ & $99.50 \%$ & $99.70 \%$ & $99.91 \%$ \\
\hline $6 \%$ & $97.80 \%$ & $98.60 \%$ & $99.10 \%$ & $99.40 \%$ & $99.60 \%$ & $99.80 \%$ & $99.93 \%$ \\
\hline $7 \%$ & $98.30 \%$ & $98.90 \%$ & $99.30 \%$ & $99.50 \%$ & $99.70 \%$ & $99.80 \%$ & $99.94 \%$ \\
\hline
\end{tabular}

54 See generally Kristelia A. Garcia \& Justin McCrary, A Reconsideration of Copyright's Term, 71 ALA. L. REV. 351 (2019) (discussing appropriate depreciation rates).

55 See Rachel Soloveichik, Books as Capital Assets, 3 (BEA Working Paper No. WP2013-11, 2013), https://perma.cc/ZH96-KG7S.

56 See Rachel Soloveichik, Music Originals as Capital Assets, 27 (BEA Working Paper No. WP2013-8, 2013), https://perma.cc/23WG-PZ49. See also Rachel H. Soloveichik, Research Spotlight: Artistic Originals as Capital Assets, 100 Am. ECON. ReV. 110 (2010), https://estadisticas.pr/files/BibliotecaVirtual/estadisticas/biblioteca/BEA_2011_ArtasCapi tal Assets.pdf.

57 Rachel Soloveichik, Music Originals as Capital Assets, 27 (BEA Working Paper No. WP2013-8, 2013), https://www.bea.gov/system/files/papers/WP2013-8.pdf. 
The value of the "product" the publisher is purchasing from the author at the time of contracting is essentially the same whether the purchase lasts for 25 years or much longer. This conclusion can be seen graphically in Figure 8:

Figure 8: Value Share of Books or Albums Earned Over Time

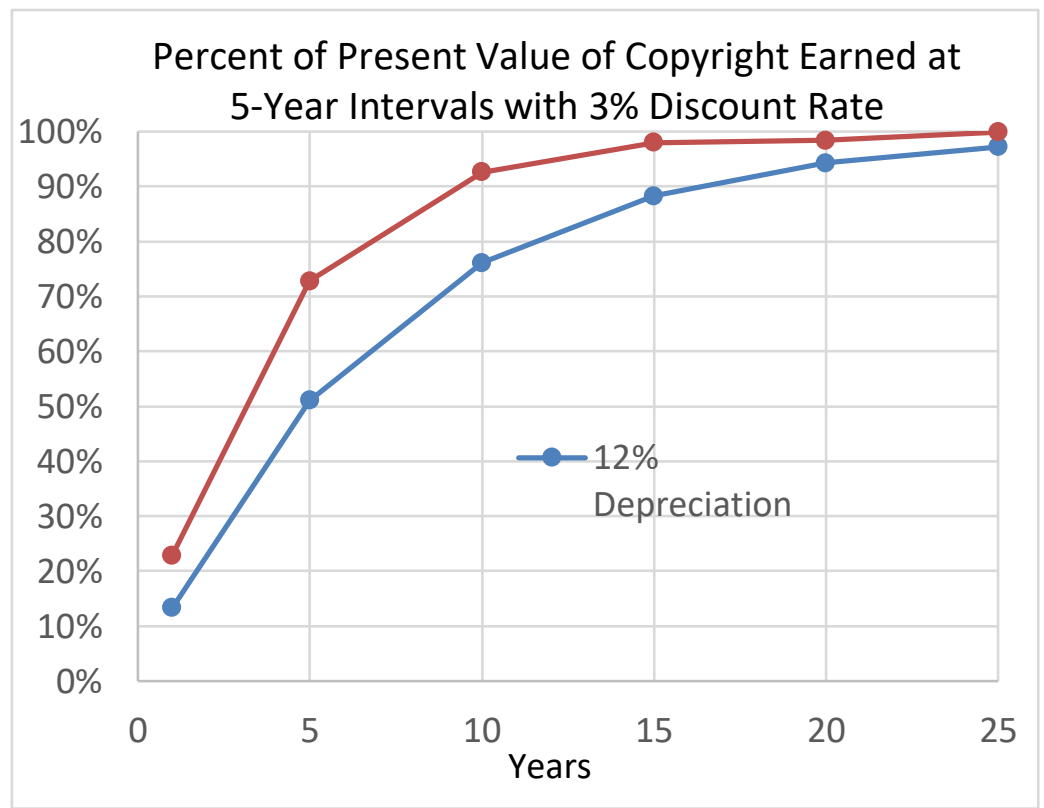

The two curves represent the NBER reported depreciation rates for books $(12 \%)$ and for albums (26\%), assuming a plausible discount rate of $3 \%$. By year 25 , a book publisher can anticipate earning $99.5 \%$ percent of the present value of the book, while a recording studio can anticipate earning $99.9 \%$ of the value of an album. Under a wide range of plausible assumptions, rights reversion at 25 years should not backfire and result in worse publishing deals for authors.

One should note that these averages fully account for the earnings of a blockbuster whose individual value might last for many decades beyond year 25 . The value of the typical book or song does not track the curve above. Many have little or no value from the start and most others earn $100 \%$ of their value in a year or two. It is the Beatles and Hemingways of the market who earn the massive dollars and prevent reality from being an L-shaped curve which would show all value from creative works realized in the first several years of distribution. In other words, the mere potential of losing the post-year-twentyfive revenue of a huge hit should not affect the business models of rational book or music publishers who already account for the blockbuster phenomenon in their decisions. 


DeMO2 (Do Not DeleTE) $1 / 12 / 2021 \quad 5: 41$ AM

\section{Public Costs of Rights ReVersion}

The legal form of rights reversion may affect the likelihood that significant economic costs will be incurred. Such costs might take the form of disincentives for publishers to invest in the production and dissemination of works; the exacerbation of orphan works problems; higher transaction costs; and potential hold-up issues for investors in derivative works. Nonetheless, this section concludes that a wide variety of potential costs are illusory or can be easily minimized.

\section{A. INVESTMENT DISINCENTIVES}

The discussion in section 6 above should allay concerns that publishers will be earning substantially less in a world where an author can only assign 25 years of rights. They will earn slightly less, but that is a private cost to publishers, not a public cost that reduces public welfare-unless reversion disincentivizes publication. As noted, rational publishers will be highly unlikely to stop investing in the exploitation of new works. Even assuming a 2\% discount rate and a 10\% depreciation rate, a publisher will still earn $94.4 \%$ of the value of the copyrighted work by year 25 . Nonetheless, one could argue that a publisher making such an assumption would forecast a 5.6\% loss in revenue over 25 years and refrain from investing quite as aggressively as before in the production of new works (a public cost). Given the realities of how reversion usually works in practice, such a scenario seems unlikely.

In book publishing, authors generally earn a percentage of revenue generated by sales over the course of a contract. When books go out of print, neither the publisher, nor the author, has any earnings, so a change to the reversion right should have no negative effect on either party. Even for books still in print, the threat of termination does not necessarily affect the contractual relationship between the author and the publisher. If the original contract was fair, say a standard $20 \%$ royalty for the author, and the book is still selling, then the author has little to gain by exercising the termination right. Other publishers are unlikely to offer more than the standard royalty, except in the very rare circumstances when the book is still a bestseller after 25 years, in which case the original publisher may have to share a larger percentage of the income (but not forego all its profits). Large established publishers should be especially immune to renegotiation. Why leave Random House for a small, independent press, even if the royalty rate is somewhat higher?

Finally, reconsider Figure 5. It shows 54\% of reversion-eligible bestsellers still in print with their original publishers. Clearly, the existence of a termination right does not result in a mass exodus of revenue-generating authors.

In sum, a 25-year termination right is unlikely to significantly change the incentive structure for book publishing. First, it will encourage authors to bring 
DeMO2 (Do Not DeleTe) $1 / 12 / 2021$ 5:41 AM

back titles that have fallen out-of-print-a clear public benefit with no cost to the original transferee. Second, authors of modestly selling books that are still in print under satisfactory publishing deals will have little incentive to switch presses. Third, some authors whose titles are selling poorly may terminate and self-publish-poor sales making it virtually impossible to find a new publisher. Finally, some authors of rare long-term bestsellers may be able to extract a higher royalty. Even given the last two scenarios, rational publishers would seem highly unlikely to diminish their overall investment in the production of new works.

\section{B. ORPHAN WORKS}

Because the Berne Convention ${ }^{58}$ prohibits member states from requiring copyright registration as a prerequisite to protection, no country has a reliable system for keeping track of who owns copyrights. ${ }^{59}$ The lack of comprehensive registries has created millions of "orphan works" whose owners are unknown and unfindable. ${ }^{60}$ The difficulty of ascertaining ownership significantly raises the cost obtaining permission to copy a work or to create a derivative work. The problem is especially acute when the author is unknown; when the author has assigned the copyright; when an assignee has made a further assignment; or when inherited rights are shared among multiple heirs. Canada has recognized the problem and partially addresses it in Section 77(1) of the Copyright Act which allows those conducting reasonable, but unsuccessful, owner searches to apply to the Copyright Board for a license to use an orphan work. ${ }^{61}$

The Berne Convention, however, does not prohibit a member state from requiring the beneficiary of a rights reversion or termination to provide public notice of its interest, and this report prefers the INDU recommendation that notification of the exercise of a termination right be filed with the Canadian Intellectual Property Office. Registration of the reversionary interest would prevent the law from creating a new class of orphan works when a publisher loses title to a claimant who is not visible to outside observers. For example, under the current law, reversion is automatic, so it is difficult to discern who owns the rights to a work of a long-dead author. Is the owner still the original publisher? More likely, it is the heirs of the author. But who are they? Where are they? How can they be contacted? If the work is out of print-like most

58 See Berne Convention for the Protection of Literary and Artistic Work, Art. 5(2), WORLD INTELLECTUAL PROPERTY ORGANIZATION, https://www.wipo.int/treaties/en/text.jsp?file_id=283698\#P109_16834 (last visited Oct. 31, 2020).

59 See Jeremy DeBeer \& Mario Bouchard, Canada's 'Orphan Works' Regime: Unlocatable Copyright Owners and the Copyright Board, 10 OxFORD U. COMMONWEALTH L.J. 215 (2010).

60 Id. Ariel Katz, The Orphans, the Market, and the Copyright Dogma: A Modest Solution for a Grand Problem, 27 Berkeley TeCH. L.J. 1285 (2013).

61 Canadian Copyright Act, R.S.C. 1985, c. C-42, s. 77 (Can.). 
DeMO2 (Do Not DeleTE) $1 / 12 / 2021$ 5:41 AM

older works - then the original publisher may likely have no idea who currently owns the reverted work and may be unable to help in the search. The problems worsen if the original publisher is uncooperative or out of business. A request as simple as permission to set an older poem to music or to re-print a photo can become a nightmare.

Notice and registration should also reduce the cost of rights reversion to publishers. When reversion is automatic, publishers are required to renegotiate for the continued use of the work with all their authors. Transactions costs in this context are non-trivial when the beneficiaries of reversion are numerous and diffuse. For marginally profitable works, publishers might conclude that the cost of transacting is not worth the trouble and simply decide to take the work out of print. On the other hand, under a notice and registration system, publishers only have to deal with the limited number of authors or their estates affirmatively seeking to exercise the right. The burden is on the claimant to contact the publisher.

A pure reversion right at year 25 , with a copyright automatically reverting to the author or its estate, might provide maximum benefit to claimants and would prevent unfairness in situations where a claimant is unaware of the existence of the termination right, but this report tentatively concludes that the potential cost to the occasional claimant is outweighed by the public benefits of notice and registration.

\section{DERIVATIVE WORKS AND THE PROBLEM OF HOLD-UP}

One of the most bedeviling problems associated with any rights reversion system is the question of how to treat the status of a properly licensed derivative work after reversion. Consider two authors who have assigned their works to a filmmaker. The first is a novelist who sold the exclusive right for her novel to be adapted into a movie. The second is the composer hired to write the music for the movie. They assigned their rights to the filmmaker at approximately the same time, and 25 years afterward would each like to exercise their termination rights. If the movie remains popular, the question arises whether those showing or selling the movie should be required to renegotiate licenses with the novelist and the composer. If negotiations fail, then the showing of the movie would likely be considered an infringement of their copyrights and potentially subject to an injunction. If an unauthorized showing of the movie after year 25 is an infringement, then either of the two author/assignors have the power to "holdup" the filmmaker and leverage a disproportionate royalty.

The phenomenon of "hold-up" is well-recognized in the economic literature and refers to the extreme negotiating leverage that the owner of an 
DeMO2 (Do Not DeleTE) $1 / 12 / 2021$ 5:41 AM

infringed input can have over the producer of the product employing the input. ${ }^{62}$ Professor Ariel Katz has noted in the copyright context that inefficiencies may result

whenever complementary inputs are each sold by a separate monopolist. Each monopolist, attempting to increase its profit, sets a monopoly price while ignoring the fact that her higher price negatively affects the demand for the complementary good. The result is that the total price the user has to pay for all complements is too high, leading to underuse or, in the extreme case, to non-use of the resource. 63

In the hypothetical above, the author or the composer separately could hold the work hostage for a maximum post-year-twenty-five royalty. Given that the filmmaker will have added substantial value beyond the story and the score, the inefficiency - and unfairness - of giving control over the distribution of the work to individual contributors is obvious. ${ }^{64}$

A former version of Canadian copyright law ${ }^{65}$ seems to have addressed the hold-up problem by denying relief to the beneficiaries of reversion in situations where the owner of the derivative work gave notice of intent to continue using the work and paid a $10 \%$ royalty. ${ }^{66}$ Under current U.S. law, authors or their estates who exercise the termination right gain no leverage at all

62 See, e.g., Mark Lemley \& Carl Shapiro, Patent Holdup and Royalty Stacking, 85 TEx. L. REV. 1991 (2007) (detailing welfare losses when patent holders on product components use infringement litigation to extract disproportionate royalties).

63 Ariel Katz, Commentary: Is Collective Administration of Copyrights Justified by the Economic Literature?, in Competition Policy and InTEllectual Property 449, 462 (Marcel Boyer, Michael Trebilcock \& David Vaver eds., 2009), cited in Ent. Software Ass'n v. Soc'y of Composers, Authors \& Music Publishers of Can., [2012] 2 S.C.R. 231, http://canlii.ca/t/fs0v7, para. 11; and Canadian Broad. Corp. v. SODRAC 2003 Inc., [2015] 3 S.C.R. 615, http://canlii.ca/t/gm8b0, para 165 (minority opinion).

${ }^{6}$ Cf. William J. Braithewaite, Derivative Works Under Canadian Copyright Law, 20 OsGoode HALL L.J. 191 (1982) ("[T] he rights of the derivative owner must be balanced against those of the underlying owner.").

65 The former reversion provision, consistent with the present provision, was found in Section 12(5) of the Copyright Act.

66 See Section 7 of the former Copyright Act (pre-reversion licensees who created authorized derivative works have the right to continued exploitation upon payment of a $10 \%$ royalty). Since the Copyright Act did not use the term "derivative work," there is some ambiguity whether the notice plus compulsory license option was available to creators of derivative works. At least one Canadian scholar favored that construction. See Braithwaite, supra note 64, at 226-28 (noting that the statute provided for the continued "reproduction of the work for sale" upon receipt of notice and payment of the $10 \%$ royalty and arguing that the intent of the statute would be advanced by construing it to protect the creator of a lawful derivative work). 
DeMO2 (Do Not DeleTE) $1 / 12 / 2021$ 5:41 AM

over the owner of a derivative work incorporating the author's inputs. Section 203(b)(1) of the U.S. Copyright Act states, "A derivative work prepared under authority of the grant before its termination may continue to be utilized under the terms of the grant after its termination, but this privilege does not extend to the preparation after the termination of other derivative works." ${ }^{67}$ Therefore, the original license granted by the author remains in force, even after termination of the underlying copyright. The novelist and composer described above would have no right to alter the original deal.

It should be noted that the United States also ameliorates the derivative works hold-up problem through its broad works-made-for-hire doctrine. In both Canada and the United States, works-made-for-hire are not subject to reversion, but in the United States, works specially commissioned for a movie or other collective work are works made-for-hire.68 In the United States, for example, the hypothetical movie score composer above would have no reversionary right to assert, while in Canada a composer might (unless the composer were an employee of the studio).

\section{WHO CAN EXERCISE THE TERMINATION RIGHT}

A problem parallel to hold-up can occur when the termination right is fragmented between numerous heirs of the author's estate. If a deceased novelist has five children with equal interests in the author's books, each child might separately seek to exercise the termination right. If the rights of each child are considered equal and vested, then the costs of negotiating continued publication of the author's novels will rise substantially. The potentially high transaction costs of dealing with multiple rightsholders is solved in U.S. law by requiring the party(ies) exercising the termination right to hold $51 \%$ of the author's interest. ${ }^{69}$ In the hypothetical above, in the United States, three of the five children would have to agree to exercise the right together, creating a single entity with whom the book publisher can negotiate. This report recommends that only a party(ies) holding $51 \%$ of the termination right should be permitted to exercise it (although all heirs should benefit equally financially from any renegotiation).

More important is the broader question of who should benefit from the termination right. Both Canadian proposals, if adopted, would differ from the U.S. termination statute in two ways. First, authors in the United States may exercise their termination right against non-exclusive licenses. This is not true of the current Canadian reversion right. In this sense, the U.S. rule benefits authors more broadly. Second, the works of some independent contractors in

6717 U.S.C. $\$ 203(b)(1)(2020)$.

68 For a commissioned work to be "made for hire," a written contract signed by the parties must say as much. See 17 U.S.C. \ 101 (2020) (defining "work made for hire.").

69 17 U.S.C. $\$ 203$ (a)(1) (2020); 17 U.S.C. \304 (4)(B)(c)(1) (2020). 
DeMO2 (Do Not DeleTe) $1 / 12 / 2021$ 5:41 AM

the United States are works-made-for-hire to which no reversion rights attach, while in Canada, only works created by people who look like formal employees are ineligible for reversion. In this sense, the Canadian rule benefits authors more broadly.

This study has collected no empirical data on the relative merits of the U.S. or Canadian rules. In the absence of data, the status quo may be the best assumption, in which case the definition of "transfer" in the proposed legislation should be defined consistently with current Canadian law to exclude nonexclusive licenses. If the Canadian works-made-for-hire doctrine remains unchanged (as is most likely), then the need to protect creators of derivative works is even greater than in the United States because of the larger class of independent contractors who could exercise the termination right.

\section{E. SPECIAL MUSIC ISSUES}

At least under the American system, the reality of the music business makes rights reversion somewhat less valuable to composers than to the writers of books. Composers generate a substantial portion of their earnings through the exploitation of their compositions in sound recordings (mechanical rights) or in the background of television shows, commercials, videos, and films (synchronization rights). ${ }^{70}$ Because studios and other artists who pay for mechanical and synchronization licenses create derivative works, under U.S. law, composers are given no leverage to renegotiate those deals under section 203(b)(1). ${ }^{71}$ In a situation where the composer is sharing profits equitably with the music publishing company, the recording studio, or a broadcaster, the American rule seems unobjectionable. In a situation as noted above, however, where the composer, received only a small lump sum payment for a composition and no royalties, inequities could clearly result.

\section{RECOMMENDATION AND CAVEAT}

This study has attempted to balance the costs and benefits of rights reversion in light of the best available data. As set forth in the executive summary, this report tentatively recommends the adoption of a right to terminate the transfer of an interest in copyright that could be exercised by the author (or heirs holding $51 \%$ of the author's interest). The author could effectuate such a termination right 25 years after the transfer was made, if the claimants provide notice to the

70 Composers also earn money by selling sheet music and licensing performances of their works on the radio, on the internet (Pandora, Spotify, and YouTube), and in live venues. Reversion should allow musicians to capture more, if not all, of the income that they currently share with their music publishing companies.

71 17 U.S.C. \$203(b)(1) (2020). They may, however, be able to renegotiate their deals with their publishers, who may be taking a percentage of the profits from existing licenses. 
transferee and register their interest in the Intellectual Property Office. Furthermore, the exercise of the termination right should have no effect against transferees who obtained a license from the author to create an original derivative work. Overall, the recommended approach is likely to improve the position of authors and their estates, while increasing net public welfare.

Although the recommended approach provides stronger protection for authors and their estates than the existing 25-year post-mortem right, the insulation of owners of properly licensed derivative works from the termination right might create inequities when an initial transfer was induced by a small lump sum payment to the author. Without data on the frequency or magnitude of lump sum copyright deals, this report cannot draw any conclusions about the need to consider an exception to the recommended rule that would enforce existing licenses to exploit derivative works. Canadian policymakers troubled by the lump sum problem might consider implementing the approach taken by the U.K. regarding the rights of creators of derivative works when a lapsed copyright is restored. In that situation, which is roughly parallel to rights reversion, U.K. law grants the creators of derivative works a continuing right of exploitation, subject to the arbitral right of owner of the newly restored copyright to pay the derivative author to forego using the work. ${ }^{72}$ This report states no position on the issue.

72 See DANIEL CHOW \& EDWARD LEE, INTERNATIONAL INTELLECTUAL PROPERTY 134 (3d ed. 2018) (author of the restored work has no right to receive royalties from the follow-on creator of a derivative but has the right to purchase rights to the derivative work). 